DOI https://doi.org/10.30525/978-9934-26-110-7-16

\title{
ОСМИСЛЕННЯ ДОЛІ УКРАЇНСЬКОГО НАРОДУ КРІЗЬ ПРИЗМУ АВТОРСЬКОГО БАЧЕННЯ НА ПРИКЛАДІ ПОЕЗІЇ ЕМІЛЯ ДУБРОВА
}

\author{
Небеленчук I. O. \\ кандидат педагогічних наук, \\ старший викладач кафедри теорії і методики середньої освіти \\ Комунальний заклад «Кіровоградський обласний інститут \\ післядипломної педагогічної освіти імені Василя Сухомлинського» \\ м. Кропивницький, Україна
}

3-поміж поетів сучасної української літератури можемо назвати таких як: Грицько Чубай, І Іван Низовий, Василь Герасим’юк, І Ігор Римарук, Іван Малкович, Кость Москалець, Мирослав Лаюк, Маріанна Кіяновська, Ліна Ланська та інші.

Розкриттю особливостей творчості сучасних поетів присвячена низка авторських праць. Так, у дослідженні «Занурення у таємниці буття як усвідомлений шлях і ключ до пізнання основ світобудови (на прикладі збірки поезій «Химерник» Віктора Крупки)» автор зазначає, що «в особливій, притаманній йому [поету] манері написання поет уводить читача у гру проводячи паралелі між реальністю та вигадкою, Явою та Навою, світлом і темінню, вічним і тлінним» [2, с. 44]. Саме така манера написання притаманна багатьом сучасним поетам.

«Поезія - ие завжди неповторність, / Якийсь безсмертний дотик до душі» - так зазначає українська поетеса Ліна Костенко. Науковиця Г. Токмань стверджує, що «лірика художньо виражає внутрішній стан людини - іï емоції, настрої, думки як реакції на зовнішні як саморефлексії» [5, с. 156]. Такою поезією, яка торкає душу, змушує іiі хвилюватися, співпереживати, вболівати, є поезія сучасного автора Еміля Дуброва. «Долі нескошена печаль» - перша збірка поета, яка вийшла у 2018 році у київському видавництві «Сільські вісті» та відрізняється самобутністю, неординарністю, наповнена неповторними образами. Вона складається 3 шести розділів. Зупинимося на розгляді віршів окремих розділів і з'ясуємо особливості поетичних творів автора.

У віршах першого розділу читачі можуть відчути авторське ставлення до «вождів». Значну низку слів застосовує Еміль Дубров до осіб, які забули про народ, змушують його страждати та животіти. Вони і лихварі, і вороги, і зрадники, і хабарники. А разом - гниле болото. Вони 
«нестримно так пнуться до влади», забувши про гідність і то «нічого, що кров на руках» і нічого, що «знову - підкуп, інтриги $i$ змови...» («Ми хрестились водою й вогнем») [1, с. 7].

Біль автора за полеглих синів у війні відчувається у вірші «Плине кача по Тисині...». Поет передає неймовірну тугу матері за полеглим сином. Виглядаючи та чекаючи сина з війни, згорьована мати просить сина хоча би пташкою прилетіти до вікна: «Хоч би пташкою, на хвилину, / Бо на світі сама-одна... / Обернуся я в тополину / I стоятиму, мов мана...» («Плине кача по Тисині...») [1, с.9]. Наслідуючи народнопісенні традиції, автор використовує образ тополі. Мати готова стояти тополею в полі, виглядаючи сина довічно. Кожен третій рядок попереднього катрену починає кожен наступний катрен. Такий повтор наближує вірш до народної пісні.

Гинуть воїни. А душа автора не відає спокою, оскільки відходять кращі. Тому «Нескошена печаль моєї долі / Блукає десь по вибалках крутих, / I серие знов стискається від болю... / Хоч не за себе, ні... Болить за тих, / Хто так любив ї̈, любив свою Вітчизну...» («Нескошена печаль моєї долі...») [1, с. 14]. Куди не сягає погляд ліричного героя, то всюди постають кургани, могили, хрести... А в могилах під хрестами не просто люди - «лежить історія великого народу». Автора хвилює доля українського народу, його збідоване протягом століть життя, його зневіра та втрата ним сили духу. Тож і ставить автор запитання насамперед самому собі: «То де ж ви, запорожиі-козаки?», «Чи ж нас осліплено?», «Невже даремно полягла Небесна сотня, / Дарма загинули Герої біля Крут?», «Невже свобода й честь уже не в моді / Серед продажності, хабарництва, інтриг?», «За щьо на намі голови иі біди?» та інші. I не знаходить відповіді на болючі запитання сьогодення. Тому зізнається: «Читаю «Кобзаря», немов молитву, / Читаю трепетно, немов Святе Письмо....» («Читаю «Кобзаря», немов молитву...») $[1$, c. 25]. Ліричний герой сподівається, що, можливо, автор «Гайдамаків» «заспокоїть» його душу.

Не менше турбує Еміля Дуброва доля українських жінок. Скільки зпоміж них юних вдів! Скільки ними пролито сліз! Ті стражденні жінки почорніли від горя. Скільки їм доводиться витримувати! «Я бачу - нині украӥнське небо / лежить на цих надломлених плечах, / $i$ нам самим молитись нині треба, / Допоки промінь світиться в очах!» («Дивлюся на вкраїнських я жінок») [1, с. 27]. Говорячи про поезію загалом, водній із авторських праць зазначено, що «характерною особливістю поезї $\epsilon$ культ жінки та жіночності» [4, с. 21]. Саме такий мотив притаманний 
поезії Еміля Дуброва. Його ліричний герой відчуває потребу вклонитися жінці доземно, подякувати їй за ії працю, відданість і життя.

«Проростає» палким словом на папері любов до України. I відлунюється та любов поета в українській пісні і в поетичному слові, у літній косовиці і «в квітучім мареві садів», ув осінніх дощових сльозинах і в зимових кучугурах снігу, оскільки ще з дитинства вчився дослухатися до звуків любові, які супроводжували допитливого хлопчика. А ще Україна - «Це маки між похилої трави, / Це ті лелеки, щзо стоять на варті» («В моєму серці гупає Майдан...») [1, с. 48].

«Ні кроку назад!» - саме такий заклик читаємо у другому розділі збірки. «Вантаж», «двохсоті», «посилка» - відразу на початку розділу постають такі слова, які пронизують усе єство, викликаючи тремтіння тіла, немов у лихоманці, а сльози невпинно стікають обличчям. I не спинити той болючий потік. Горе матерів і дружин, смерть чоловіків, сльози дітей - ось які картини розгортаються перед читачами. Хрести, хустини, могили, домовини... Здається, людське серце не витримає такої напруги. Здається, що воно розірветься від неймовірного болю. Постають невмирущі образи: крила, журавлі, трава, світанок, «блакитноока квітка». I слідом за автором хочеться вірити у світлість прийдешнього дня без війни, без вибухів, без сліз, без страждання, коли «відвиють «гради», відгремлять гармати», «Щоб над землею небо було ясне, / Щоб не тримали зброю ми в руках» («Згадаймо тих, хто не дожив до свята...») [1, с. 67]; «Я вірю, переможе Україна, / На ноги міино стане, в повен зріст, / Не згине наша мова солов '̈̈на / I дзвони битимуть лише на благовіст!» [1, с. 89].

У збірці натрапляємо на віршовані рядки «Вічної книги буття», у якій автор 3 безмежною любов'ю пише про дітей, ділиться спогадами дитинства, вірить у силу слова, плекає надії на краще майбуття, милується красою полів, вдихає та слухає звуки землі: «Вдихаю запахи весняної землі / На повні груди, ніби наостанок. / То й що, що піт на зоранім чолі, / Я вдячний долі за чудовий ранок!» [1, с. 119]. Там, де пращурів святі могили, де «батькове святе напутнє слово», де «пісня, що лунає за столом», де «круті дніпровські схили», там і $є$ ота «Свята земля» - найкраща, найрідніша, найдорожча. Ліричний герой, однак як і автор, зрісся 3 тією землею, він від прадіда-діда хлібороб. Він зізнається, що «бракує часом слів», щоб висловити ту безмежну любов до рідної землі, яка переповнює груди. Тому автор 3 неймовірною радістю вдихає запахи весни, зачаровується, «як ввечір матіола пахне п'янко», «як сонще будить жайворона спів», i «бринять сльозою росяні світанки». Згадуючи прожиті роки, пригадує автор і напутнє мамине слово: «Знаєщ, синку, / 
Не варт тужити, / Що посивіла голова... / Щастя - просто на світі жити!». Жити! У цьому сутність людського шляху. Насолоджуватися кожною прожитою миттю, радіти усьому, що є довкола, вбирати красу світу та вбачати їі в найменших здавалося, дрібницях, - у подиху вітру, в усміху волошок, у сльозах неба, у поцілунку сонячного променя. Переповнює душу автора радість від споглядання, як «розивітають на шибах мімози», як «туман осінній сірий / Котить, ніби сірий кінь», як «осінь підбирає кольори», як вітер роздягає калину, зриваючи 3 неї листочки, як «блакитноока дівчинка Весна / Уже зелені розплітає коси», як «з самого ранку дощик завітав», як «земля смарагдовим рум'янцем зашарілась». Бачимо доволі сильну образність, неймовірні порівняння, надзвичайну чутливість. Тож автор зізнається: «Я живу! Я ще тут!.. І безмежно люблю июю красу.»

Про що не писав би автор, у його поезії завжди знаходимо відгук на події, що відбуваються, на те, що бентежить його душу. Його поезія болюча і прониклива до сліз, коли ідеться про загибель воїнів, тяжку долю жінок-вдів, про дітей-сиріт, чиї батьки загинули від ворожих куль. Його поезія також неймовірно лірична та ніжна, коли пише про найсвятіше почуття - кохання, що супроводжується побаченнями, зізнаннями, очікуваннями, поцілунками, щастям. «Гармонійне поєднання людських почуттів і краси природи» [3, с. 130] є одним із основних аспектів поезії автора. Поезія Еміля Дуброва чиста, трепетна, зворушлива, коли йдеться про колискові пісні мами, напутні слова батька, милі та рідні стежини до батьківського порогу. Автор доводить стару істину: «Хай що там $є$-життя сильніше смерті!».

\section{Література:}

1. Дубров Еміль. Долі нескошена печаль. К. : «Сільські вісті», 2018. 224 c.

2. Небеленчук I. О. Занурення у таємниці буття як усвідомлений шлях і ключ до пізнання основ світобудови (на прикладі збірки поезій «Химерник» Віктора Крупки)». Всесвітня література в школах Украӥни. 2020. № 6. С. 43-48.

3. Небеленчук I. О. Сонце у творах світової літератури: навчальнометодичний посібник. К. : ТОВ «Праймдрук», 2012. 249 с.

4. Небеленчук I. О. Філософське осмислення лірики Сергія Висєканцева крізь призму «Срібного століття»: дослідницький контент. Всесвітня література в школах України. 2016. № 11. С. 15-23.

5. Токмань Г. Л. Методика навчання української літератури в середній школі: підручник. К. : ВЦ «Академія», 2012. 312 с. 